\title{
Scenarios of the China's ADIZs above the South China Sea
}

\author{
Le Duy Tran*
}

Even though no international legal instrument explicitly provides the right for States to establish ADIZs, such zones have been unilaterally declared since the 1950s. China's ADIZ above the Senkaku/Diaoyu Islands - a disputed area in the East China Sea and her recent activities in disputed maritime features in the South China Sea have given rise to concerns about other ADIZs that Beijing may possibly establish above this area. In that context, this paper ventures to draw some potential ADIZs, which may be established by China above the South China Sea, and predicts diplomatic and legal reactions from other States.

\section{Keywords}

SCS ADIZ, South China Sea, Paracel, Spratly, Nine-dash Line, UNCLOS, EEZ

\section{Background}

Air Defense Identification Zones ("ADIZs") are a point of issue of the 21st century's international law. ADIZs may be defined as:

[s]pecial designated airspace of defined dimensions within which aircraft are required to comply with special identification and/or reporting procedures additional to those

* Research fellow of the University of Melbourne. LL.B. (Diplomatic Academy of Viet Nam), LL.M. (Melbourne). ORCID: http://orcid.org/0000-0002-8557-4817. The author would like to convey my sincere thanks to Dr. Nguyen Dang Thang, Diplomatic Academy of Viet Nam and Ms. Pham Ngoc Minh Trang, Faculty of International Relations, University of Social Science and Humanity, Viet Nam National University Ho Chi Minh City for their support and advice during this research. The author may be contacted at: duytranle86@gmail.com / Address: No. 181, Doi Can Str., Ward/Commune: Ba Dinh Dist., Ha Noi, Viet Nam DOI: http://dx.doi.org/10.14330/jeail.2016.9.1.12 
related to the provision of air traffic services. ${ }^{1}$

ADIZs are established to identify aircraft approaching territorial airspaces of a State for security purposes. ${ }^{2}$ The Zones help States to recognize potential danger from foreign aircraft, thereby enhancing their national security. ${ }^{3}$ In other words, the very purpose of ADIZs is to give States enough time to prepare for a potential air attack. ${ }^{4}$ Within such areas, foreign aircraft must adhere to requirements concerning identification, including submiting their flight plans, maintaining two-way radio communications, and operating the secondary radar transponder. ${ }^{5}$

ADIZs are usually "established in international airspace adjacent to sovereign airspaces of States." A notable example is China's ADIZ above the East China Sea. ${ }^{7}$ Recently, however, China is expected to establish another ADIZ above the South China Sea ("SCS ADIZ"), where China has territorial and maritime disputes with other coastal States. A number of official statements have been made by representatives of States to emphasize such issue. E.g., Admiral Harry Harris, Commander of the US Pacific Command ("US-PACOM"), on February 25, 2016, expressed his concern about an ADIZ that Beijing would establish above the South China Sea. ${ }^{8}$ Such concerns are built on a solid foundation of ambiguous and provocative statements coming out of Beijing. The spokesman of China's Ministry of Defense, on November 23, 2013, announced that China would establish another ADIZ "at appropriate time after completing preparations," which was repeated at

1 Convention on International Civil Aviation of 1944, 15 U.N.T.S. 102 (entered into force on April 4, 1947) Annex XV (Aeronautical Information Services) [1.1].

2 R. Abeyratne, In Search of Theoretical Justification for Air Defence Identification Zones, 5 J. TRANSP. SECURITY 88 (2012).

3 N. Grief, Public International Law in the Airspace of the High Seas 147 (1994).

4 K. Hsu, 'Air Defense Identification Zone' Intended to Provide China Greater Flexibility to Enforce East China Sea Claims. See also Staff Report, US-China Economic and Security Review Commission (2014) at 1, available at http:// www.uscc.gov/sites/default/files/Research/China\%20ADIZ\%20Staff\%20Report.pdf (last visited on May 13, 2016). [Emphasis added]

5 S. Jinyuan, The East China Sea Air Defense Identification Zone and International Law, 14 ChINESE J. InT'L L. 275 (2015).

6 Supra note 4.

7 Jae Woon Lee, Tension on the Air: The Air Defense Identification Zones on the East China Sea, 7 J. EAST AsIA \& INT'L L. 274-81 (2014)

8 US Naval Institute, PACOM Harris: US. Would Ignore A 'Destabilizing' Chinese South China Sea Air Defense Identification Zone (Feb. 26, 2016), available at https://news.usni.org/2016/02/26/pacom-harris-u-s-would-ignore-adestabilizing-chinese-south-china-sea-air-defense-identification-zone (last visited on May 3, 2016).

9 China Exclusive: Defense Ministry Spokesman Responds to Air Defense Identification Zone Questions Xinhuanews, Nov. 23, 2013, available at http://news.xinhuanet.com/english/china/2013-11/23/c_132912145.htm (last visited on May 3, 2016). 
the Regular Press Conference of the Ministry of Foreign Affairs held on November 28, 2013. ${ }^{10}$ On May 7, 2015, while reaffirming the 'right' to establish ADIZ if its air safety was threatened, Chinese Foreign Ministry Spokesperson Chunying Hua indicated that the situation in the South China Sea did not require China to do that. ${ }^{11}$

In 2015, China announced that it completed its land reclamation and construction activities at its occupied features in the Spratly Islands. ${ }^{12}$ At the hearing in the US House Armed Services Committee on April 15, 2015, Admiral Locklear, former Commander of the US - PACOM, predicted that China's land reclamation in the South China Sea would enable her to deploy significant military equipment necessary for the enforcement of an ADIZ if Beijing wanted to do so. ${ }^{13}$ China's ADIZ establishment in the South China Sea will, as expected, elicit possible diplomatic and legal reactions from other countries concerned. In that context, this essay tackles some possible questions regarding China's potential ADIZs above the South China Sea.

\section{ADIZs above the South China Sea: Three Scenarios}

\section{A. ADIZ above the Paracel Islands}

In 1996, China declared its archipelagic baselines surrounding the Paracel Islands. ${ }^{14}$ In addition, Article 2 of China's Exclusive Economic Zone and Continetal Shelf Act of 1998 provides that China's exclusive economic zone ("EEZ") and continetal shelf extend "to a distance of $200 \mathrm{~nm}$ from the baselines from which the breadth of the

10 Mission of Taiwan to European Union, Defense Ministry Spokesman Yang Yujun's Response to Questions of ADIZ at Regular Press Conference (Nov. 28, 2013), available at http:/www.fmprc.gov.cn/ce/cebe/eng/xnyfgk/t1109759.htm (last visited on May 3, 2016).

11 Foreign Ministry Spokesperson Hua Chunying Regular Press Conference on May 7, 2015, available at http://www. fmprc.gov.cn/mfa_eng/xwfw_665399/s2510_665401/t1261660.shtml (last visited on May 4, 2016).

12 Foreign Ministry Spokesperson Lu Kang 'Remarks on Issues Relating to China's Construction Activities on the Nansha Islands and Reefs' (June 16, 2015), available at http://www.fmprc.gov.cn/mfa_eng/xwfw_665399/ s2510_665401/2535_665405/t1273370.shtml (last visited on May 3, 2016).

13 Admiral Samuel Locklear, PACOM House Armed Services Committee Testimony (Apr. 15, 2015) US-PACOM, available at http://www.pacom.mil/Media/SpeechesTestimony/tabid/6706/Article/585188/pacom-house-armedservices-committee-testimony.aspx (last visited on May 3, 2016).

14 Declaration of the Government of the People's Republic of China on the Baselines of the Territorial Sea (May 15, 1996), available at http://www.un.org/Depts/los/LEGISLATIONANDTREATIES/PDFFILES/CHN_1996_ Declaration.pdf (last visited on May 3, 2016). 
territorial sea is measured." 15 Pursuant to these legal instruments, it can be seen that China claims $200 \mathrm{~nm}$ EEZ and continental shelf from the Paracel Islands. Therefore, the Chinese potential ADIZ above the Paracel Islands may extend beyond the airspace above China's claimed $12 \mathrm{~nm}$ territorial sea around the archipelago to that above its claimed EEZ and continental shelf. Such an ADIZ will likely overlap the airspaces above the EEZs and continental shelves of Viet Nam and the Philippines. Concurrently, it may also overlap the Flight Information Regions ("FIRs") Ho Chi Minh, Sanya and Manila (Figure 1).

Figure 1: Potential ADIZ above the Paracel Islands (dotted line $)^{16}$

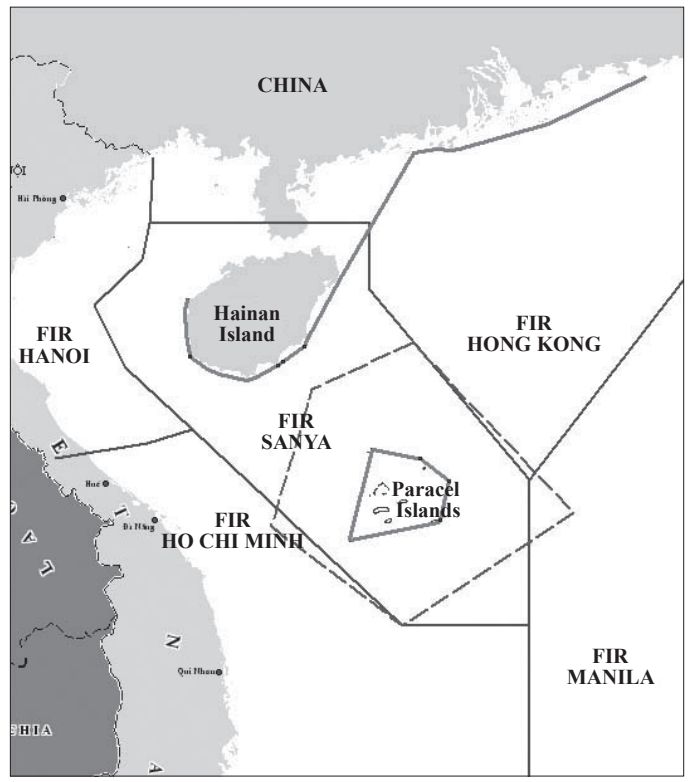

China has continuously claimed that the Paracel Islands is under its sovereignty. This position was officially affirmed in Note Verbal No. CML/17/2009 dated 07 May 2009 of the Permanent Mission of China in the United Nations, which maintained that: "China has indisputable sovereignty over islands in the South China Sea and the adjacent waters..."17 ADIZs are established in international airspace which are

15 Exclusive Economic Zone and Continental Shelf Act of the People's Republic of China (June 26, 1998) art 2, available at $\mathrm{http} / /$ www.un.org/Depts/los/LEGISLATIONANDTREATIES/PDFFILES/chn_1998_eez_act.pdf (last visited on May 3, 2016).

16 Compiled by the author.

17 Note Verbale No. CML/17/2009 of the Permanent Mission of the People's Republic of China to the United Nations (May 
adjacent to territorial airspaces of States so that a Zone should depart from the sovereign airspace of the originating State. China's East China Sea ADIZ, e.g., departs from the airspace above its continental territory and territorial sea, certainly not from the airspace above the Diaoyu/Senkaku islands. As that airspace is just part of the ADIZ, rather than the departure point of the zone, establishing the ADIZ there may not be seen as a legal affirmation about China's sovereignty over the Diaoyu/Senkaku Islands. Nevertheless, Japan has maintained an ADIZ above the Islands since $1972^{18}$ so that China's ADIZ may be witnessed as a reaction to the Japanese one. In any event, if China's potential ADIZ above the Paracel Islands is declared, however, it will definitely depart from the airspace above the archipelago and its territorial sea, measured from the baselines claimed by China in $1996 .^{19}$ Consequently, the ADIZ will be an affirmation of China's claim not only over the archipelago, but also the $200 \mathrm{~nm}$ EEZ and Continental Shelf attributed to it.

The ADIZ can also help China to control aviation activities in the northern part of the South China Sea. China seemingly acquires sufficient conditions to establish an ADIZ above the Paracel Islands. First, as China declared the baselines surrounding the archipelago, it would not be difficult for Beijing to establish the ADIZ in the airspace outside its claimed territorial sea. In addition, the airport in Woody Island of the Paracel Islands guarantees military actions for the ADIZ's enforcement actions. More importantly, the Paracel archipelago is the only subject of the bilateral dispute between China and Viet Nam, the latter being consistent in pursuing its sovereignty claim over the Paracels. ${ }^{20}$ The sovereignty claim over the Paracel archipelago is basically bilateral; only Viet Nam invoked its claimed sovereignty over the Paracels to reject China's Note Verbal No. CML/17/2009, ${ }^{21}$ although Viet Nam and Malaysia jointly protested against the China's extension of continental shelf limit beyond 200 nautical miles on the basis of its claims on the sovereignty over Paracel and Spratly

7, 2009), available at $\mathrm{http}: / /$ www.un.org/depts/los/clcs_new/submissions_files/mysvnm33_09/chn_2009re_mys_vnm_ e.pdf (last visited on May 3, 2016). [Emphasis added]

18 Supra note 4 , at 3

19 US Dept. of State, 117 Limits in the Seas: Straight Baselines Claim: China 17 (July 9, 1996), available at http://www. state.gov/documents/organization/57692.pdf. For details on China's base lines, see Hyun-soo Kim, China's Basepoints and Baselines under the United Nations Convention on the Law of the Sea: A Critical Analysis, 6 J. EAST AsIA \& InT'L L 135-53 (2013), available at http://yijuninstitute.blogspot.kr/2015/12/chinas-basepoints-and-baselines-under.html (all last visited on May 12, 2016).

20 See, e.g., MOFA Spokesperson Le Hai Binh, Remarks on China's Recent Activities in Hoang Sa Archipelago (Mar. 17, 2016), available at http://www.mofa.gov.vn/en/tt_baochi/pbnfn/ns160318232341; MOFA Spokesperson Le Hai Binh, Remarks on Award of the Tribunal in the Arbitration instituted by the Philippines against China (Oct. 31, 2015) available at $\mathrm{http} / / / \mathrm{www} . \mathrm{mofa} . g o v . v n / \mathrm{en} / \mathrm{tt} \_$baochi/pbnfn/ns151104142526 (all last visited on May 4, 2016).

21 Supra note 17. 
archipelagoes. ${ }^{22}$ With the foregoing findings, legally speaking, an ADIZ above the Paracel Islands may be the most likely one established by China above the South China Sea.

\section{B. ADIZ above the Spratly Islands}

The Spratly Islands is the subject of the sovereignty dispute between six parties, comprising five States (Brunei, China, Malaysia, the Philippines, and Viet Nam) and Taiwan. China may create an ADIZ above the Spratly Islands in order to strengthen her sovereignty claims over this group of islands. In its Note Verbal No. CML/8/2011 dated 14 April 2011, China explicitly claimed that:

[u]nder the relevant positions of the 1982 United Nations Conventions on the Law of the Sea, as well as the Law of the People's Republic of China on the Territorial Sea and the Contiguous Zone (1992) and the Law on the Exclusive Economic Zone and the Continental Shelf of the People's Republic of China (1998), China's Nansha [Spratly] Islands is fully entitled to Territorial Sea, Exclusive Economic Zone (EEZ) and Continental Shelf. ${ }^{23}$

The ADIZ would thus help China to reaffirm such viewpoint. Nevertheless, China needs to weigh up the pros and cons before establishing an ADIZ above the Spratly Islands. First, such an ADIZ may overlap FIRs Ho Chi Minh, Manila, Singapore and Kota Kinabalu (Figure 2) so that it may elicit criticisms from Viet Nam, the Philippines, Singapore and Malaysia, respectively. In addition, due to the sovereignty dispute over the Spratly Islands, the ADIZ may be confronted with reactions derived from all parties to the disputes. As the Spratly archipelago locates in a strategic area of navigation and aviation, the ADIZ may face strong criticisms of many other States who have interest in aviation over this area.

22 Note Verbal No. 86/HC-2009 of the Permanent Mission of the Socialist Republic of Viet Nam to the United Nations (May 8, 2009), available at $\mathrm{http} / /$ www.un.org/depts/los/clcs_new/submissions_files/vnm37_09/vnm_re_chn_2009re vnm.pdf. See also Note Verbal No. HA 24/09 of the Permanent Mission of Malaysia to the United Nations (May 20, 2009), available at $\mathrm{http}: / / \mathrm{www} . u n . o r g / \mathrm{depts} / \mathrm{los} / \mathrm{clcs} \_$new/submissions_files/mysvnm33_09/mys_re_chn_2009re_mys vnm_e.pdf (last visited on May 4, 2016).

23 Note Verbale No. CML/8/2011 (Apr. 14, 2011), available at http://www.un.org/depts/los/clcs_new/submissions_files/ mysvnm33_09/chn_2011_re_phl_e.pdf (last visited on May 3, 2016). 
Figure 2: Potential ADIZ above the Spratly Islands (dotted line) ${ }^{24}$

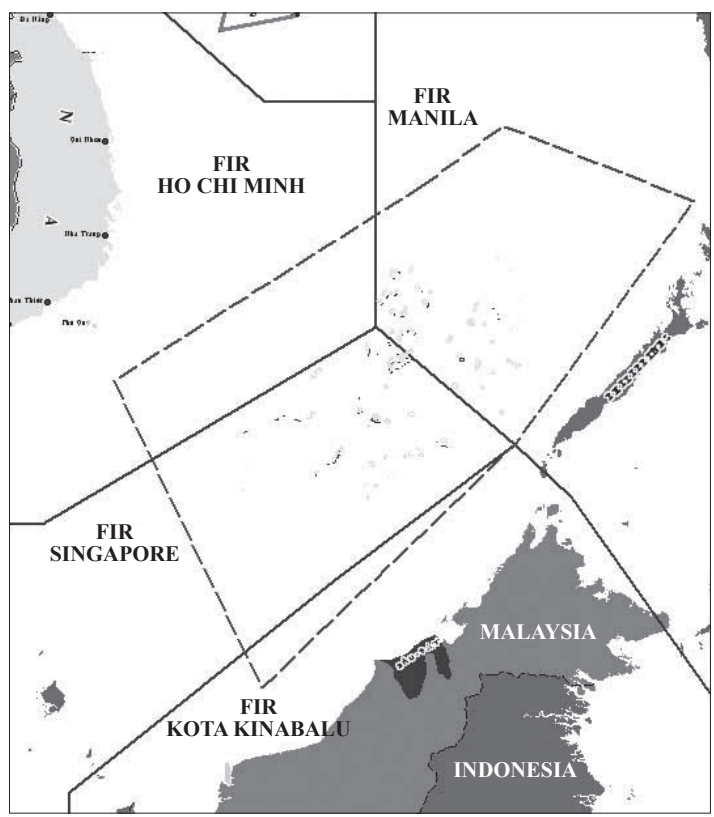

The ADIZ above the Spratly Islands would then receive more condemnations from not only parties of the South China Sea dispute, but also other relevant States such as the US, Japan, Australia and even Singapore. There is also a technical issue for establishing the SCS ADIZ. In order to set up exact coordinates of the ADIZ's points, China needs to declare the territorial sea of the Spratly Islands or each feature of the archipelago. Such declaration, however, would lead to another dispute in addition to the already severely criticized reclamation and construction work recently undertaken by China on the features in the Spratly Islands. Moreover, the US Navy deployed destroyer USS Lassen within the $12 \mathrm{~nm}$ belts of features reclaimed by China. ${ }^{25}$ Despite condemnations of China, ${ }^{26}$ the US Department of State declared on October 27, 2015 that this deployment demonstrated the principle of freedom navigation in international water. ${ }^{27}$ In the letter dated 5 January 2016 to Senator John McCain, the

24 Compiled by the author.

25 J. Odom, FONOPs to preserve the right of innocent passage?, DipLomat, Feb. 25, 2016, available at http://thediplomat. com/2016/02/fonops-to-preserve-the-right-of-innocent-passage (last visited on Apr. 30, 2016).

26 Foreign Ministry Spokesperson Lu Kang Regular Press Conference (Oct. 27, 2015), available at http://www.fmprc. gov.cn/mfa_eng/xwfw_665399/s2510_665401/2511_665403/t1309625.shtml (last visited on May 3, 2016).

27 Department of State Spokesperson John Kirby Daily Press Briefing (Oct. 27, 2015), available at http://www.state.gov/ $\mathrm{r} / \mathrm{pa} / \mathrm{prs} / \mathrm{dpb} / 2015 / 10 / 248870 . \mathrm{htm}$ (last visited on May 3, 2016). [Emphasis added] 
US Secretary of Defense Ash Carter reaffirmed, on the one hand, that the destroyer USS Lassen "conducted a [Freedom of Navigation Operation] in the South China Sea" but on the other hand, he regarded the Freedom of Navigation Operation as the right of innocent passage in territorial sea and the freedom of navigation on the high seas. ${ }^{28}$ Even though such clarification of the US Secretary of Defense is not straightforward to conclude the legal nature of the operation, it may illustrate the American viewpoint to challenge China's territorial claims over the features and its reclamations there.

China must carefully consider before establishing an ADIZ above the Spratly Islands because this action would not have positive, but negative impact on its national interest in the region. Moreover, the ADIZ may contradict the statements of China's Foreign Minister Wang Yi at the ASEAN regional forum on August 6, 2015 that: "The situation in the South China Sea is stable on the whole, and there is no possibility of major conflicts" and after the reclamation, China will only invest in "facilities mainly for public good purposes" such as search and rescue, maritime scientific research, etc. ${ }^{29}$

\section{ADIZ above the Nine-dash Line}

In Note Verbal No. CML/17/2009 dated 07 May 7 2009, China officially announced its nine-dash line claim, ${ }^{30}$ which should be considered as ground of the potential China's SCS ADIZs. However, the SCS ADIZ will not be appropriate mainly because its physical ground - the nine-dash line - itself remains ambiguous at best. ${ }^{31}$ In spite of its official introduction in 2009, China has neither explained the legal characteristic of its claim, nor published the exact geographic coordinates of the line. By contrast, if China announces an ADIZ above the nine-dash line, it will have to declare the exact coordinates of the Zone to define the airspace because foreign aircraft must adhere to its identification rules within the framework of the ADIZ. In that context, the ADIZ above the nine-dash line will demonstrate the exact location of the line which

28 Secretary of Defense Ash Carter, Letter to McCain on South China Sea Freedom of Navigation Operation (Jan. 5, 2016), US Naval Institute, available at http://news.usni.org/2016/01/05/document-secdef-carter-letter-to-mccain-onsouth-china-sea-freedom-of-navigation-operation (last visited on May 3, 2016).

29 Ministry of Foreign Affairs of the People's Republic of China, Wang Yi on the South China Sea Issue at the ASEAN Regional Forum (2015), available at http://www.fmprc.gov.cn/mfa_eng/zxxx_662805/t1287277.shtml (last visited on May 3,2016). [Emphasis added].

30 Supra note 17.

31 Hong Thao Nguyen, Vietnam's Position on the Sovereignty over the Paracels \& the Spratlys: Its Maritime Claims, 5 J. EAST AsIA \& INT’L L. 203-7 (2012), available at http://yijuninstitute.blogspot.kr/2015/12/vietnams-position-on-sovereignty-over. html (last visited on May 3, 2016). 
contradicts the Chinese policy.

If following the nine-dash line map attached to Note Verbal No. CML/17/2009, the potential ADIZ above the line may overlaps FIRs Sanya and Hong Kong of China, FIRs Ha Noi, Ho Chi Minh, Manila, Singapore and Kota Kinabalu controlled by other States. (Figure 3) Therefore, akin to the ADIZ above Spratlys, this ADIZ will be criticized by the States responsible for managing these FIRs above the South China Sea. Moreover, the nine-dash line has also been criticized by a non-claimant State in the South China Sea disputes such as Indonesia. ${ }^{32}$ Therefore, an additional act relating to the claim will induce a stronger protest from Jakarta.

Figure 3: Potential ADIZ above the Nine-dash Line (dotted line) $)^{33}$

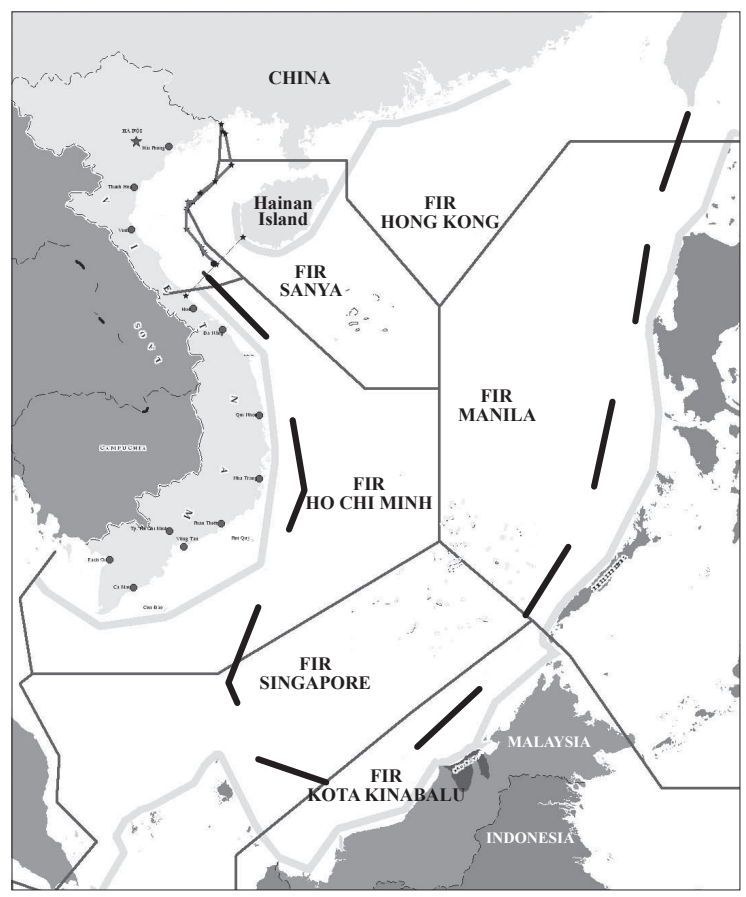

Another critical issue regarding the ADIZ above the nine-dash line will be the legal challenge of the Philippines over the line through the Arbitral Tribunal under

32 Note Verbale No.480/POL-703/VII/10 of the Permanent Mission of the Republic of Indonesia in the United Nations (July 8, 2010), available at $\mathrm{http}: / /$ www.un.org/depts/los/clcs_new/submissions_files/mysvnm33_09/idn_2010re_mys_ vnm_e.pdf (last visited on May 3, 2016).

33 Compiled by the author. 
Annex VII of the UNCLOS. ${ }^{34}$ Even though China continuously denies the Tribunal's jurisdiction over the case and her adherence to any of its awards, ${ }^{35}$ she would not carry out any new aggressive action relating to the nine-dash line. On October 29, 2015, the Tribunal, by way of the Award on the jurisdiction and admissibility, reserved "a decision on its jurisdiction with respect to" the legitimacy of China's claim to 'historic rights' within the nine-dash line. This jurisdiction will be examined during the consideration in connection with the merit of the issue. ${ }^{36}$ Although the Tribunal has not satisfied itself concerning the jurisdiction over the nine-dash line, it did not totally refuse to consider the issue. The Tribunal has been considering its jurisdiction over the nine-dash line since the Hearing on the merits of the case held on November 24-30, 2015. ${ }^{37}$ Despite China's prompt expression that the Award had "no binding effect on China,"38 Beijing is expected to postpone the declaration of the ADIZ based on the line until the final Award of the Tribunal.

In short, although China seems to prepare to declare and enforce the SCS ADIZs, it needs to weigh the pros and cons of such ADIZs. The most likely scenario therefore is an ADIZ just above the Paracel Islands.

34 Award on Jurisdiction and Admissibility (Phil. v China), UNCLOS Arbitral Tribunal, PCA Case No 2013-19 (Oct. 29, 2015), at 26, available at http://www.pcacases.com/web/sendAttach/1506 (last visited on May 3, 2016).

35 See, e.g., Permanent Court of Arbitration, Press Release on Arbitration between the Republic of the Philippines and the People's Republic of China: Arbitral Tribunal Establishes Rules of Procedure and Initial Timetable (Aug. 27, 2013), available at http://www.pcacases.com/web/sendAttach/227; Vice Foreign Minister of China Liu Zhenmin Remarks at the 2014 ARF Senior Officials' Meeting (June 9, 2014), available at http://www.fmprc.gov.cn/mfa_eng/ wjbxw/t1 165765.shtml; Government of the People's Republic of China, Position Paper on the Matter of Jurisdiction in the South China Sea Arbitration Initiated by the Republic of the Philippines (Dec. 7, 2014), available at http://www. fmprc.gov.cn/mfa_eng/zxxx_662805/t1217147.shtml; Foreign Ministry Spokesperson Hua Chunying Remarks on the Conclusion of the Hearing on Issues Relating to Jurisdiction and Admissibility by the South China Sea Arbitral Tribunal Established at the Request of the Philippines (July 14, 2015), available at http://www.fmprc.gov.cn/mfa_eng/ xwfw_665399/s2510_665401/2535_665405/t1281250.shtml (all last visited on May 3, 2016).

36 Supra note 34, at 399.

37 Department of Foreign Affairs of the Republic of the Philippines, Statement on the Philippine Arbitration Case (Nov. 10, 2015), available at http://www.dfa.gov.ph/index.php/newsroom/dfa-releases/7836-statement-on-the-philippinearbitration-case (last visited on May 3, 2016).

38 Ministry of Foreign Affairs of the People's Republic of China, Statement on the Award on Jurisdiction and Admissibility of the South China Sea Arbitration by the Arbitral Tribunal Established at the Request of the Republic of the Philippines (Oct. 30, 2015) available at $\mathrm{http} / /$ www.fmprc.gov.cn/mfa_eng/zxxx_662805/t1310474.shtml. See also Foreign Ministry Spokesperson Lu Kang Regular Press Conference (Oct. 30, 2015), available at http://www.fmprc. gov.cn/mfa_eng/xwfw_665399/s2510_665401/t1310709.shtml (all last visited on May 3, 2016). [Emphasis added] 


\section{Diplomatic and Legal Reactions relating to the ADIZs}

Due to the strategic location of the South China Sea and the nature of the South China Sea disputes, China's SCS ADIZs will give rise to more tensions between China and other States comparing to the ADIZ it established above the East China Sea.

\section{A. Diplomatic Reactions}

As mentioned above, the South China Sea witnesses complicated disputes concerning the sovereignty over maritime features as well as other maritime issues relating to the application of the UNCLOS. Once China establishes the SCS ADIZs, the parties concerned will immediately accuse China of escalating the dispute, instablizing the status quo of the South China Sea in both bilateral and regional forums.

Many States have their national interests for maintaining peace, stability and freedom in the South China Sea due to its strategic location in terms of aviation and navigation. If any State tries to fully control this area, it will face challenges from the others. President Obama, e.g., in his statement at the 2012 East Asia summit in Phnom Penh, reaffirmed that the US has national interests in peace and stability in the South China Sea on the basis of "international law, unimpeded lawful commerce, and freedom of navigation." 39 If China imposes the same identification rules of the ECS ADIZ on its potential SCS ADIZs, those States having interest either in aviation and navigation such as the US, or in controlling FIRs in this area, such as Singapore and Indonesia will strongly protest that action.

\section{B. Legal Reactions}

Legal questions of the SCS ADIZs may be submitted to the Council of the International Civil Aviation Organization by the members States of the Council, such as Singapore and Malaysia. ${ }^{40}$

39 See Fact Sheet: East Asia Summit Outcomes (Nov. 20, 2012), The White House, available at https://www.whitehouse. gov/the-press-office/2012/11/20/fact-sheet-east-asia-summit-outcomes (all last visited on May 3, 2016). [Emphasis added]

40 Japan initiated similar legal procedures against the China's ECS ADIZ within the framework of the ICAO. See Jaemin Lee, China's Declaration of an Air Defense Identification Zone in the East China Sea: Implications for Public International Law, 18 ASIL InsIGHTs, Aug. 19, 2014, available at https://www.asil.org/insights/volume/18/issue/17/ china $\%$ E2\% $\% 0 \% 99$ s-declaration-air-defense-identification-zone-east-china-sea; Ministry of Foreign Affairs of Japan, 201st Session of the Council of the International Civil Aviation Organization (ICAO) (Mar. 11 2014), available at 
The Arbitral Tribunal under Annex VII of the UNCLOS affirmed that in spite of China's non-recognition of and non-participation in the arbitral proceedings, China is the party of the case initiated by the Philippines and is thus bound by the Tribunal's awards. ${ }^{41}$ Therefore, if China establishes an ADIZ above either the Spratly Islands or the nine-dash line, the Philippines will be able to request the Tribunal to prescribe provisional measures relating to the ADIZ under Article 290, paragraph 1 of the UNCLOS. The request may be submitted to the Tribunal to reserve the Philippine rights before the final award. ${ }^{42}$ In $M / V$ "Louisa," the International Tribunal for the Law of the Sea ("ITLOS") indicated that provisional measures could not be prescribed unless the Tribunal found "a real and imminent risk that irreparable prejudice may be caused to the rights of the parties in dispute." 43 In the present case, the Philippines requested the Arbitral Tribunal to decide that:

(1) The nine-dash line contravenes the UNCLOS (submission 2);

(2) Some Spratlys' maritime features occupied by China, such as Mischief Reef and Second Thomas Shoal appertain to the Philippine Continental Shelf (submission 5). ${ }^{44}$

Although the Tribunal reserved the decisions about its jurisdiction to the abovementioned issues, ${ }^{45}$ they have not been rejected from the case. If China established the ADIZs above the Spratlys or the maritime space within the nine-dash line, Manila might argue that these ADIZs would prevent the Philippines from exercising normal aviation activities in the airspace above its EEZ and Continental Shelf, induce irreparable economic harms to the Philippines, and interfere with the Philippines' freedom of overflight above its EEZ enshrined in the UNCLOS. [Emphasis added] This argument seemingly meets the condition set out by the ITLOS in M/ $V$ "Louisa" to render provisional measures. Thus, it may become the legal basis for the Philippines to request provisional measures of the Arbitral Tribunal, in order to prevent China from enforcing the ADIZs, pending the final decisions of the Tribunal. Similar to the Philippines, other parties of the South China Sea disputes may

http://www.mofa.go.jp/press/release/press4e_000225.html (all last visited on May 4, 2016).

41 Supra note 34, at 114. [Emphasis added]

42 United Nations Convention on the Law of the Sea of 1982, 1833 U.N.T.S. 3 (entered into force Nov. 16, 1994) art 290.1 .

43 M/V Louisa (Saint Vincent and the Grenadines v Kingdom of Spain, Order, 2010, ITLOS 72 (Dec. 23), Case No 18, available at $\mathrm{https} / /$ www.itlos.org/fileadmin/itlos/documents/cases/case_no_18_prov_meas/18_order_231210_en.pdf (last visited on 4 May 2016).

44 Supra note 34, at 147.

45 Id. at $399 \& 402$. 
initiate the arbitral proceedings under Annex VII of the UNCLOS against China's SCS ADIZs in the light of Articles 58 and 87 of the UNCLOS. Concurrently, they may request the ITLOS to prescribe provisional measures under Article 290, paragraph 5 of the UNCLOS, pending the constitution of the Arbitral Tribunal. ${ }^{46}$

In sum, due to the South China Sea's strategic role, its stability is integral part of national interests of many States in this region. Therefore, any aggressive action implemented in this area, such as the ADIZ declaration may confront with diplomatic and legal challenges. In the light of the Arbitral Tribunal's Award delivered on October 29, 2015, other parties in the South China Sea disputes will have more confidence to pursue legal means in order to prevent the enforcement of these aggressive actions.

\section{Conclusion}

Hardly does international law shed any light on the legal basis for States to establish and maintain ADIZs. Besides the aforementioned definition on ADIZ enshrined in Annex XV of the Convention on International Civil Aviation, international air law neither regulates the legal nature of ADIZ, nor explicitly provides the power for States to establish such zones. ${ }^{47}$ Today, international lawyers would maintain two contradictory positions towards this issue. While some protagonists, such as Dutton, argue that international law allows States to establish these zones, ${ }^{48}$ the antagonists, such as Cuadra, do not accept any legal basis of these declarations. ${ }^{49}$ Nevertheless, ADIZs have been unilaterally created since 1950s and a limited number of these zones were criticized by other States as well as the international community as a whole.

The ECS ADIZ established by China crystallizes diplomatic conflicts between concerning States. It also raises questions on the legal basis of the ADIZs, which are established in disputed areas overlapping FIRs of other States.

As China's reclamation and construction in some features in the South China Sea, her potential SCS ADIZs also give rise to concerns for States in the region despite

46 UNCLOS art 290.5.

47 C. Lamont, Conflict in the Skies: The Law of Air Defence Identification Zones, 39 AIR \& Space L. 193 (2014).

48 P. Dutton, Caelum Liberum: Air Defense Identification Zones outside Sovereign Airspace, 103 Am. J. INT'L L. 709 (2009).

49 Supra note 47 , at 192. 
China's avowal of the lawfulness and peaceful purposes of these activities. In this context, China's SCS ADIZs will absolutely escalate political conflicts in the region. 